\title{
Moral Altruis dalam Filsafat Sosial Perspektif Perbandingan dengan Akhlak dalam Islam dan Pengaruhnya terhadap Ekonomi
}

\author{
Muhammad Djakfar \\ Penulis adalah Dosen Fak. Ekonomi Universitas Islam Negeri (UIN) Malang
}

\section{ABSTRACT}

The term Altruist moral can be corresponded with al-akhlaq al-mahmudah (good moral). The word "altruist" derives from "altruistic" (English) which means a character that emphasizes on other needs. Therefore, someone with altruist moral can be called as a person who has a character that emphasizes on other needs.

Globalization era which is dominated by rapid development of information and technology has carried out an enormous changes to the life of society in many factors, including economy. Recently, many people begin to question again about competence as well as moral role and ability to manage and control moral of society that becomes more permissive, not submissive anymore as occurred in the past.

Analysis result says that whether in social philosophy or Islam, Altruist moral will deliver economic attitude which orients to do the obligation first than asking for the right to its own necessity (individual egoist - annaniyah). Altruist moral, referred to Yusuf Qardhawi, will widely give effect on the whole aspect of economy, whether in the case of production, consumption, circulation or distribution. 


\section{Pendahuluan}

Dalam kehidupan sehari-hari, seringkali kita dengar tiga istilah yang sangat populer dan populis sekali, yakni akhlak, moral dan etika. Ketiganya, sangat akrab kedengarannya di telinga kita sehingga tidak terpikirkan apakah kata-kata ini mempunyai makna yang sama atau sebaliknya. Kalau kita cermati, tampaknya dari berbagai literatur yang mengkaji tentang moral memberikan terminologi yang secara substansial mengandung makna yang sama, yaitu tentang norma kebaikan yang dihadapkan pada norma keburukan.

Akan tetapi menurut penulis persoalannya lain lagi, kendati ruang perbedaan itu tidak ada karena dianggap tidak prinsipiil, sebenarnya bila dilihat dari aspek tolok ukur masing-masing, perbedaan itu jelas ada. Kata "akhlaq" yang berasal dari bahasa Arab, kemudian diadopsi menjadi bahasa Indonesia yaitu "akhlak" tolok ukurnya adalah al-Qur'an dan Hadits. Namun demikian kata seperti itu tidak ditemukan dalam al-Qur'an. Yang ditemukan hanyalah bentuk tunggal kata tersebut, yaitu khuluq yang tercantum dalam al-Qur'an surat al-Qalam ayat 4 yang artinya "Sesungguhnya engkau (Muhammad) berada di atas budi pekerti yang agung " Kata Akhlak di sini biasanya menyangkut perilaku manusia secara lahir maupun batin. ${ }^{2}$ Sekedar ilustrasi bisa diberikan contoh, apabila kita melihat seseorang yang berangkulan pada saat berjumpa dengan orang lain misalnya, perilaku ini merupakan simbol bahwa kedua orang tersebut sangat akrab,saling menghargai, saling menghormati dan sebagainya. Tetapi di balik perilaku lahir yang tampak baik itu, sebenarnya hati ( $q a l b)$ salah seorang di antara mereka berdua tidak tulus, dengki, jahat dan sebagainya, maka orang yang mempunyai perilaku hati yang demikian dapat dikatakan belum berakhlak. Inilah kelebihan ajaran akhlak dalam Islam.

Selanjutnya istilah moral yang berasal dari akar kata mores (Latin) yang berarti kebiasaan, maka tolok ukurnya adalah kebiasaan yang berlaku. Seseorang dikatakan amoral jika ia berperilaku berseberangan dengan kebiasaan perilaku di sebuah tempat. Ukuran moral bisa jadi bersifat lokal sehingga tidak sama antara satu tempat dengan tempat yang lain. Sebagai contoh, dalam satu, atau beberapa hal tidak sama antara kebiasaan di negeri Jepang dan negeri Indonesia. Sebagai konsekuensinya seseorang yang pernah hidup di kedua negeri tersebut 
harus berperilaku sesuai dengan kebiasaan setempat agar tidak dikatakan sebagai manusia yang tidak bermoral.

Adapun istilah etika, dikatakan tolok ukurnya adalah akal-pikiran. Seseorang dengan akal sehatnya bisa menimbang-nimbang apakah perbuatan atau perilakunya etis, atau sebaliknya. Seseorang yang meludah di dekat orang yang sedang menikmati makanan, maka bisa dikatakan perilaku orang itu tidak etis, karena di sini ada ukuran universal secara akal sehat bahwa ludah itu benda yang menjijikkan sehingga tidak layak dikeluarkan di sembarang tempat, terutama di dekat orang yang sedang makan.

Demikianlah perbedaan ketiga istilah tersebut menurut hemat penulis sebagai wacana untuk meluruskan pemahaman yang selama ini telah lama berkembang. Namun demikian, diskursus ini tidak berpretensi untuk mempermasalahkan perbedaan tersebut. Dalam arti, ruang ini memberi terminologi yang sama terhadap istilah akhlak, moral dan etika. Hal ini dimaksudkan untuk mengantisipasi penggunaan istilah yang tidak sama antara ahli yang satu dengan ahli yang lain yang dipakai dalam buku mereka masing-masing. Padahal yang dimaksud secara substansial adalah sama, yaitu persoalan norma kebaikan dan keburukan yang menjadi timbangan perilaku kehidupan manusia.

Zaman sekarang yang dikenal dengan sebutan era globalisasi yang didominasi oleh pesatnya perkembangan informasi dan teknologi telah membawa perubahan besar terhadap kehidupan masyarakat dalam banyak segi. Perubahan itu membawa kemajuan yang begitu luar biasa, sekaligus menimbulkan kegelisahan di kalangan orang banyak. Perkembangan ilmu pengetahuan dan teknologi telah menjadikan planet bumi ini kian menyempit, seakan-akan sekat antar daerah dan antar bangsa tidak lagi menjadikan penghalang untuk melakukan komunikasi dan mengakses informasi yang sangat cepat. Manusia zaman dahulu yang begitu gelap pengetahuannya tentang ruang angkasa, kini mulai terkuak lebar dengan bantuan kemampuan teknologi yang diciptakannya sendiri.

Semuanya itu telah membawa perubahan besar dalam perilaku manusia yang menjadi wilayah kompetensi moral. Sekarang banyak orang mulai mempertanyakan kembali kompetensi, sekaligus peran dan kemampuan moral untuk mengatur dan mengendalikan moral masyarakat. Semakin hari perilaku masyarakat kian permissive, tidak submissive lagi dalam memegani nilai moral 
yang terpuji. Kalau kita cermati secara jujur dan objektif, sikap-sikap seperti ini telah banyak merambah ke dalam berbagai segi dan lini kehidupan masyarakat.

Dalam menghadapi situasi yang sedemikian itu, muncul beragam pertanyaan. Masih mungkinkah kita merumuskan kembali norma-norma universal di bidang moral? Apabila mampu, masihkah kita mempunyai i'tikad baik untuk melaksanakan hasil rumusan itu, karena tanpa dukungan subjek pelaku, norma moral tidak akan bermakna dalam kehidupan. Tentu saja pertanyaan ini hanya bisa dijawab dengan hati nurani, baik secara individual maupun kolektif.

Rasanya kita tidak dapat memilih salah satu dari tiga sistem norma moral yang secara tradisional ditawarkan, yakni norma berdasarkan keyakinan akan kewajiban mutlak (deontologis), norma berdasarkan tujuan perbuatan (teleologis), atau norma berdasarkan hubungan-hubungan dengan orang lain (relasional). Sebaiknya ketiga sistem itu dipadukan bersama untuk mencari kebenaran moral secara tepat. ${ }^{3}$

Hal lain yang kiranya perlu kita sadari sejak awal bila kita mengusahakan penilaian moral ialah bahwa moral yang menyangkut individu mesti dibedakan dari moral yang berhubungan dengan hidup dan urusan orang banyak. Memang, moral yang menyangkut individu pun punya kaitan dengan lain. Tetapi kaitan itu tidak sekuat pada moral sosial yang langsung menyangkut orang banyak. Moralitas masturbasi, misalnya, tidak melibatkan begitu banyak orang lain bila dibandingkan dengan moralitas sistem politik atau sistem ekonomi. Karena itu tuntutan terhadap moralitas sistem sosial mesti lebih diperhatikan dibandingkan dengan tuntutan terhadap moral seksual individual. ${ }^{4}$

Untuk membicarakan masalah-masalah moral yang begitu luas, diskursus ini sengaja dibatasi pada masalah moral dalam hubungannya dengan ekonomi. Hal ini sangat penting dikemukakan karena persoalan ekonomi menyentuh kehidupan masyarakat luas. Penulis bertolak dari sebuah asumsi, bahwa ada hubungan yang signifikan antara moral dengan ekonomi. Perilaku pelaku ekonomi tidak lepas dari kualitas moral yang mengendalikan perjalanan hidupnya. Semakin teguh dan konsisten mereka memegangi nilai moral, niscaya akan semakin konsisten memperhatikan hak dan kewajiban dalam berekonomi. Dalam realitas, moral berekonomi ini dalam segala aspeknya semakin longgar. Dampak yang kian terasa dan kian meluas di Indonesia adalah semakin banyaknya masyarakat 
yang hidup di bawah garis kemiskinan. Kondisi ini sangat erat hubungannya dengan kian runtuhnya nilai moral di kalangan para pelaku ekonomi di negeri ini.

Bertolak dari kenyataan di atas diskursus ini diharapkan bisa ikut menambah wawasan baru, sekaligus kontribusi pemikiran baru bagaimana kedua sistem moral dari bersumber yang berbeda ikut mengarahkan perilaku para pelaku ekonomi sesuai dengan tuntunan moral yang terpuji.

\section{Moral Altruis dalam Filsafat Sosial $1^{5}$}

Istilah moral altruis kalau kita cari padanannya dalam ajaran akhlak dalam Islam, mungkin bisa disamakan dengan akhlak terpuji (al-akhlaq al-mahmudah). Al-Ghazali mengkategorikan dua kelompok akhlak, yaitu kelompok akhlak terpuji dan tercela (al-akhlaq al-madzmumah). Masing-masing kelompok terdiri dari sepuluh macam akhlak yang pada biasanya menjadi materi kajian dalam dunia pendidikan Islam di Indonesia hingga sekarang.

Kata "altruis " berasal dari kata "altruistic" (Inggris) yang berarti sifat mementingkan orang lain. ${ }^{6}$ Dengan demikian orang yang bermoral altruis dapat dikatakan sebagai orang yang memiliki sifat mementingkan orang lain. Atau, orang yang berjiwa sosial, sebagai lawan orang yang selalu mementingkan diri sendiri (egois-individualis).

Ahli biologi, menurut Scott Gordon, mendefinisikan "aitruism" sebagai tingkah laku yang menguntungkan pihak lain dengan kerugian tertentu, atau resiko kerugian, pada diri sendiri. ${ }^{7}$ Gordon menjelaskan bahwa moral seperti ini (altruism) tidak hanya dimiliki oleh manusia, namun juga dimiliki oleh binatang. Dalam hal ini ia mengilustrasikan perilaku gajah Afrika. Jenis jantan spesis ini hidup menyendiri secara individual, tetapi betina dan anak-anaknya, membentuk kelompok kecil yang terdiri dari sepuluh sampai dua puluh anggota yang mencari makan bersamasama, membela diri secara kolektif, dan membesarkan anak secara kolektif pula. Para anggota saling membantu satu sama lain dalam mencari makan. Gajah yang masih anak-anak diperhatikan oleh gajah dewasa tanpa membedakan orangtua biologisnya, konflik antar anggota kelompok tidak dikenal, setidak-tidaknya, terlalu jarang atau terlalu ringan sehingga tak teramati. Apabila seekor anggota dari kelompok gajah terluka, yang lain cepat membantu. Jika bahaya mengancam, 
semua gajah dewasa terlibat dalam satu strategi pertahanan yang terorganisir, kecuali pemimpinnya yang menentukan taktik dan mengambil posisi terdepan dalam menghadapi bahaya. ${ }^{8}$ Gambaran organisasi sosial gajah seperti ini berarti ada kecenderungan untuk berpartisipasi dalam tingkah laku altruistis.

Selanjutnya, Gordon mengatakan bahwa manusia itu binatang yang bersifat alturistis. Ia mengambil contoh bangsa Amerika memberikan sumbangan untuk meringankan korban gempa bumi di Armenia; para dokter Perancis mengorbankan diri mereka sendiri untuk memerangi penyakit di Chad; petugas pemadam kebakaran mempertaruhkan nyawa mereka, dengan bayaran rendah, berusaha untuk mengeluarkan penghuni dari gedung yang terbakar. Semua masyarakat manusia (dengan kekecualian yang jarang seperti suku Ik dari Uganda) merawat orang tua, fakir miskin dan orang cacat. Semua masyarakat modern mempunyai sistem altruisme yang terorganisir, mengenakan pajak pada para anggota untuk membantu yang lain yang tidak dapat membayar makan, perumahan, pendidikan, atau pelayanan kesehatan. ${ }^{9}$ Altruisme merupakan sebuah ciri penting dari sosialitas dalam masyarakat manusia, baik dalam lingkungan keluarga maupun masyarakat luas. Satu ciri dari masyarakat modern adalah meluasnya lingkup aktivitas yang bersifat altruistis, terutama aktivitas yang diorganisir oleh pemerintah. Peran altruisme dalam sosialitas manusia, apa peran dan apa seharus-nya, merupakan tema utama dalam literatur pemikiran sosial. ${ }^{10}$

Jika yang dimaksud kata "peran" dan "seharusnya" itu kita kaitkan dengan persoalan ekonomi, maka bisa diterjemahkan bagaimanakah peran moral altruis dalam ekonomi dan bagaimana pula seharusnya ekonomi dikelola sesuai dengan tatanan moral yang berlaku. Selanjutnya bagaimana perbedaan dan persamaan dengan peran moral (akhlak) yang bersumber dari ajaran Islam.

Itulah gambaran peta pemikiran yang akan dikaji lebih lanjut dalam diskursus ini dalam mengkomparasikan antara dua moral dari tolok ukur yang berbeda dan selanjutnya bagaimana pengaruhnya terhadap masalah ekonomi.

\section{Akhlak dalam Islam}

Dalam pengertian sehari-hari, akhlak diartikan sebagai budi pekerti, watak, tabiat." Kata akhlak kendati berasal dari bahasa Arab, namun kata seperti itu 
tidak ditemuka dalam al-Qur'an. Yang ditemukan hanyalah bentuk tunggal kata tersebut yaitu khuluq, sebagaimana telah disinggung di atas.

Kata akhlak justru banyak ditemukan di dalam hadits-hadits Nabi Saw., antara lain dalam sebuah hadits yang sangat populer yang diriwayatkan oleh Malik : "Aku hanya diutus untuk menyempurnakan akhlak yang mulia".'2

Bertolak dari pengertian bahasa di atas di mana akhlak diartikan sebagai budi pekerti, ini berarti bahwa dalam akhlak terkandung nilai baik maupun buruk. Hal ini sesuai dengan terminologi yang dikemukakan oleh Ahmad Amin dalam bukunya $A l$-Akhlaq bahwa akhlak (etika) ialah suatu ilmu yang menjelaskna arti baik dan buruk, menerangkan apa yang seharusnya dilakukan oleh seseorang kepada orang lain, mengarahkan tujuan yang harus dituju oleh manusia dalam perbuatan mereka dan menunjukkan jalan untuk melakukan apa yang harus diperbuat. ${ }^{13}$ Para filosof dan teolog mengkaji tentang arti baik dan buruk, dan dalam kaitan dengan perilaku manusia, selalu mempertanyakan apakah perilaku itu merupakan hasil pilihan manusia sendiri atau berada di luar kemampuannya? Namun demikian perlu diakui bahwa dalam diri manusia terdapat potensi yang mengarah kepada dua kutub perilaku yang berseberangan yakni baik atau buruk. Hal ini bisa dipahami dari firman Tuhan : "Dan Kami telah menunjukkan kepadanya dua jalan". Yang dimaksud "dua jalan" dalam ayat ini adalah jalan kebajikan dan jalan kejahatan. ${ }^{14}$ Dalam surat yang lain, Tuhan berfirman : ...dan jiwa serta penyempurnaannya (ciptaannya), maka Allah mengilhamkan kepada jiwa itu (jalan) kefasikan dan ketakwaannya". ${ }^{15}$

Kendati kedua potensi itu terdapat dalam diri manusia, namun ditemukan isyarat-isyarat dalam al-Qur'an bahwa kebajikan lebih dahulu menghiasi diri manusia daripada kejahatan, dan bahwa manusia pada dasarnya cenderung kepada kebaikan. Hal ini sebagaimana penjelasan Tuhan : "durhakalah Adam kepada Tuhannya dan sesatlah ia"16

Menurut M. Quraish Shihab, redaksi ayat ini menunjukkan bahwa sebelum digoda oleh Iblis, Adam tidak durhaka, dalam arti, tidak melakukan sesuatu yang buruk, dan bahwa akibat godaan itu, ia menjadi tersesat. Walaupun kemudian Adam bertobat kepada Tuhan, sehingga ia kembali lagi pada kesuciannya. ${ }^{17}$

Kecenderungan manusia terhadap kebajikan, atau pandangan tentang kesucian manusia sejak lahir, banyak dijelaskan dalam hadits Nabi Saw. Antara lain hadits yang diriwayatkan Bukhari :"Setiap anak dilahirkan dalam keadaan 
suci (fitrah), hanya saja kedua orang-tuanya (lingkungannya) yang menjadikan dia Yahudi, Nasrani, atau Majusi". Demikian pula yang diriwayatkan Ahmad dan Ad-Darimi, yangmenceritakan bahwa seorang sahabat Nabi Saw. bernama Wabishah bin Ma'bad berkunjung kepada Nabi Saw., lalu beliau menyapanya dengan bersabda :"Engkau datang menanyakan kebaikan? "Benar, wahai Rasul." Jawab Wabishah. "Tanyailah hatimu!" Kebaikan adalah sesuatu yang tenang terhadap jiwa, dan yang tenteram terhadapnya hati, sedangkan dosa adalah yang mengacaukan hati dan membimbangkan dada, walaupun setelah orang memberimu fatwa"18

Dengan kedua potensi itu yang dimiliki manusia untuk melakukan kebaikan dan keburukan, serta kecenderungannya yang mendasar kepada kebaikan, seharusnya mengantarkan manusia untuk melakukan semua titah Tuhan (agamaNya) yang dinyatakan sesuai dengan fithrah (asal kejadian manusia). Sesuai firman-Nya : "Maka hadapkanlah wajahmu dengan lurus kepada agama (Allah); tetaplah atas fitrah Allah yang telah menciptakan manusia menurut fitrah itu. Tidak ada perubahan atas fitrah Allah. Itulah agama yang lurus, tetapi kebanyakan manusia tidak mengetahuinya."

Di sisi lain, karena kebaikan merupakan pilihan manusia, kelak di hari kemudian pada masa pertanggungjawaban, manusia dihadapkan kepada dirinya sendiri : "Bacalah kitabmu, cukuplah dirimu sendiri pada waktu ini sebgai penghisab terhadapmu."20

Berdasarkan uraian di atas, al-Qur'an pada prinsipnya menghadapkan manusia pada dua alternatif pilihan dengan mempertanggungjawabkan konsekuensinya sendiri. Dalam Islam tidak dikenal manusia membebankan konsekuensi perbuatannya (dosa) kepada orang lain. Semuanya akan kembali pada dirinya sendiri, asalkan memenuhi kreteria, pertama, manusia tidak diminta untuk mempertanggungjwabkan apa yang tidak diketahui atau tidak mampu dilakukannya; kedua, manusia tidak dituntut mempertanggungjawabkan apa yang tidak dilakukannya, sekalipun hal tersebut diketahuinya; dan ketiga, pertanggungjawaban tersebut berkaitan dengan perbuatan yang disengaja, bukan gerak refleks yang tidak melibatkan kehendak. ${ }^{21}$

Lalu apa yang menjadi parameter perilaku baik dan buruk menurut terminologi akhlak dalam Islam? Jawabnya adalah bahwa parameter itu harus merujuk kepada ketentuan Allah. Demikian ketentuan yang telah ditetapkan oleh 
sebagian besar ulama. ${ }^{22} \mathrm{Hal}$ ini adalah sangat wajar, karena apa yang dinilai baik oleh Allah, tujuannya pasti baik dan akan membawa kepada kebahagiaan. Demikian pula sebaliknya, segala sesuatu yang dinilai buruk oleh Allah, niscaya hasil akhirnya adalah keburukan dan penderitaan, baik di dunia maupun di akhirat.

Lain halnya dengan pendapat Ahmad Amin. Guru besar Universitas AlAzhar, Kairo Mesir ini menyatakan bahwa parameter akhlak, pertama, adalah adat istiadat, dengan argumen bahwa dalam segala tempat dan waktu, manusia itu terpengaruh oleh adat-istiadat golongan dan bangsanya. Ia hidup di dalam lingkungan mereka, melihat dan mengetahui bahwa mereka melakukan sesuatu perbuatan dan menjauhi perbuatan lainnya. Dengan demikian, ia mengikuti sebagian besar perbuatan yang mereka lakukan, atau yang mereka tinggalkan. Parameter yang kedua, adalah menurut paham hedonism yang menyatakan bahwa ukuran baik dan buruk ialah kebahagiaan. Kebahagiaan itu merupakan tujuan akhir dari hidup manusia. Mereka mengartikan kebahagiaan adalah kelezatan, bukan kepedihan. Kelezatan bagi mereka ialah ukuran perbuatan. Maka perbuatan yang mengandung kelezatan itu baik, sebaliknya yang mengandung kepedihan, ituiah perbuatan yang buruk. ${ }^{23}$

Akhlak dalam ajaran Islam tidak dapat disamakan dengan terminologi etika yang hanya dibatasi pada norma sopan santun antar sesama manusia, dan hanya berkaitan dengan perilaku lahiriah. ${ }^{24}$ Istilah "Akhlak" lebih komprehensif maknanya, sebagaimana telah disinggung dalam uraian pendahuluan, karena juga mencakup berbagai hal yang bersifat batiniah. Akhlak diniah (Islam) mencakup berbagai ranah dan sasaran, yang dimulai dari akhlak terhadap Allah hingga akhlak terhadap sesama manusia dan alam lingkungan di mana manusia hidup.

Sekedar ilustrasi, dapat diberikan contoh dalam aktivitas ekonomi. Jika para pelaku bisnis menghindari praktek monopoli, menghargai hak konsumen, mengeplorasi sumber daya alam dengan memperhatikan pelestarian alam dan lingkungan, ini mengandung makna bahwa mereka itu menjunjung tinggi akhlak terhadap sesama manusia dan alam lingkungan. Hal ini harus dilakukan oleh pelaku ekonomi karena kesemuanya itu pada akhirnya harus dipertanggungjawabkan kepada Tuhan yaitu Dzat yang memiliki dan menguasai semua makhluk cintaanNya. 


\section{Pengaruh Moral terhadap Ekonomi : Antara Filsafat Sosial dan Islam}

Pada bagian ini akan dikaji bagaimana pengaruh moral terhadap ekonomi, baik moral altruis menurut versi filsafat sosial maupun akhlak yang bersumber dari ajaran Islam. Moral altruis di sini sengaja dibatasi pada kajian moral yang dikemukakan Scott Gordon dalam bukunya The History and Philosophy of Social Science. Di luar pendapat ini sifatnya hanya sebagai argumen pendukung untuk mempertajam analisis yang akan dilakukan. Demikian pula akhlak dalam Islam adalah akhlak yang bersumber dari al-Qur'an dan hadits, termasuk pendapat para ahli yang dianggap relevan.

Sebagaimana arti altruis itu sendiri yang sifatnya mementingkan orang lain daripada dirinya sendiri. Maka jika sikap ini diaplikasikan dalam aktivitas ekonomi, berkecenderungan akan melahirkan perilaku humanis yang selalu mendahulukan kewajiban, di samping memperhatikan apa yang menjadi hak orang lain dan lingkungan. Perilaku semacam ini tidak akan merugikan dan menimbulkan bencana bagi pihak lain, karena pelakunya sadar akan kewajiban moral yang harus didahulukan. Jika semua pelaku ekonomi bersikap altruistik demikian, maka keselarasan hidup bermasyarakat akan terwujud dan terus bisa dipertahankan. Dengan demikian sikap moral altruis secara tidak langsung telah mendukung dari sebuah tesis Leibnizian yang menyatakan bahwa kehidupan semesta ini telah dikuasai sejak awal mula oleh suatu imperativa keselarasan. Dengan kata lain, alam semesta ini pada hakikatnya adalah suatu tertib keselarasan yang telah terwujud secara pasti sejak awal mulanya. Inilah yang disebut a pre-establised harmonius order. Tuhan Mahakuasa dan Mahasempurna, dan Dialah Pencipta semesta ini. Penciptaan tentulah didasari oleh suatu intensi, maksud atau alasan yang mengisyaratkan adanya tujuan yang final (causa finalis). ${ }^{25}$

Bisa kita bayangkan jika para pelaku ekonomi tidak mempunyai komitmen moral altruis, dalam sekala makro mereka akan merasa bebas mengeksploitasi sumber daya alam, seperti hutan, mineral, kekayaan laut dan lain sebagainya, tanpa memperhatikan pelestarian dan dampaknya terhadap lingkungan. Para pemilik modal bebas melakukan praktek monopoli, pemilik pabrik bebas mengeksploitasi tenaga kerja manusia secara tidak manusiawi dengan upah yang tidak memadai. Demikian pula dalam skala mikro, bisa digambarkan bagaimana 
seorang penjual mencuri takaran, mengelabui kualitas barang dan lain sebagainya, yang kesemuaya ini merupakan indikator ketidakadilan terhadap konsumen.

Menurut Adam Smith, tujuan utama manusia adalah untuk mencapai kondisi yang lebih baik. Dengan demikian Adam Smith cenderung melihat manusia sebagai makhluk yang tidak pernah puas, yang selalu menginginkan peningkatanpeningkatan. Konsepsi yang dikemukakan Smith cenderung memandang manusia sebagai makhluk yang hanya tertarik pada kemakmuran ekonomi dan hanya peduli pada miliknya sendiri. Menurut Gordon, penafsiran seperti ini tentu saja salah. Keinginan manusia untuk mencapai peningkatan dalam hal ekonomi tidak berarti bahwa mereka tidak menginginkan tercapainya kemajuan atau peningkatan pada dimensi-dimensi yang lain, dan kepedulian manusia hanya pada miliknya sendiri tidak berarti bahwa manusia tidak memberikan nilai apa pun pada milik dan kondisi orang lain. ${ }^{26}$

Selanjutnya Gordon mengemukakan pendapat Smith yang menyatakan bahwa manusia mempunyai kemampuan untuk bersimpati secara rasional terhadap orang lain. Yaitu kemampuan untuk menempatkan diri dalam posisi orang lain, secara mental, sehingga dia dapat merasakan apa yang dirasakan atau dialami oleh orang lain. Dengan cara ini kita akan bisa merasakan dan memikirkan keinginan, harapan, kesenangan, penderitaan dan rasa takut yang dirasakan oleh orang lain. Kemampuan seperti ini akan sangat membantu manusia dalam mencurahkan segala pikiran dan tindakannya untuk membentuk "sentimen moral."27 Selain itu, Smith juga berpendapat bahwa manusia melakukan tindakan yang bermoral karena mereka sangat menghargai keinginan dan batas-batas yang dibuat oleh orang lain. Oleh karenanya, motif-motif yang berorientasi pada kepentingan pribadi akan cenderung dibatasi oleh moralitas yang telah diterima secara umum oleh masyarakat. ${ }^{28}$

Dalam mencermati pendapat Smith itu, ada inkonsistensi pemikiran yang mengundang kontroversi, sebagimana telah dikemukakan oleh Gordon di atas. Inkonsistensi dalam hal ini terpahami karena di satu sisi manusia,manurut Smith, mempunyai sikap empati dan simpati yang sangat altruis, sangat peduli pada kepentingan eksternal di luar dirinya sendiri. Namun di sisi lain, ia menyatakan bahwa manusia adalah makhluk yang hanya tertarik pada kemakmuran ekonomi dan hanya peduli pada miliknya sendiri. Ini berarti bahwa dalam persoalan kepemilikan, yang berkait erat dengan masalah ekonomi, manusia jauh bersifat 
egoistis-individualistis. Suatu sifat yang sangat kontroversial dengan sifat moral altruis yang humanis. Kiranya corak pemikiran seperti inilah yang banyak mendominasi pemikiran ekonomi kapitalis di era modern yang hingga dewasa ini banyak mengontrol perkembangan ekonomi dunia.

Lalu bagaimana halnya dengan akhlak dalam Islam? Jika kita berbicara tentang nilai akhlak dalam ekonomi dan mu'amalah Islam, maka tampak secara jelas di hadapan kita empat nilai utama, yaitu : Rabbaniyyah (Ketuhanan), Akhlak, Kemanusiaan dan Pertengahan. ${ }^{29}$ Nilai-nilai ini mencerminkan keunikan dalam ekonomi Islam yang tidak dimiliki oleh sistem ekonomi mana pun di dunia.

Nilai-nilai tersebut merupakan karakteristik syariat Islam yang kaafah, sempurna dalam segala dimensinya. Atas dasar karakteristik itu ekonomi Islam jelas berbeda dengan sistem ekonomi konvensional karena ia adalah sebuah sistem ekonomi Ilahiah, ekonomi humanistis, ekonomi moralistis dan ekonomi moderat. Makna dan nilai-nilai pokok yang empat ini mempunyai dampak terhadap seluruh aspek ekonomi, baik dalam masalah produksi, konsumsi, sirkulasi maupun distribusi. Semua itu terpola oleh nilai-nilai tersebut, karena jika tidak, niscaya ke-Islam-an itu hanya sekadar simbol tanpa makna.

Hal yang membedakan antara sistem Islam dengan sistem maupun agama lain, adalah adanya hubungan erat antara ekonomi dan akhlak, seperti halnya hubungan antara ilmu dan akhlak, antara politik dan akhlak, antara perang dan akhlak, antara agama dan negara, dan antara materi dan rohani. Akhlak adalah daging dan urat nadi kehidupan Islami. ${ }^{30}$ Hubungan ini tidak lepas dari tujuan pokok risalah kenabian yakni untuk menyempurnakan akhlak, sebagaimana sabda Rasulullah Saw. riwayat Malik : "Aku hanya diutus untuk menyempumakan akhlak yang mulia".

Islam sama sekali tidak memperkenankan pemeluknya mendahulukan kepentingan ekonomi di atas kepentingan pemeliharaan nilai dan keutamaan yang diajarkan agama. Tidak seperti sistem-sistem lain yang lebih mendahulukan keuntungan ekonomi dengan mengabaikan norma akhlaki dan berbagai konsekuensi keimanan. Kesatuan antara ekonomi dan akhlak akan semakin jelas pada setiap aktivitas ekonomi, baik yang berkaitan dengan produksi, distribusi , sirkulasi, dan konsumsi. Seorang muslim - secara pribadi maupun kolektif - tidak bebas melakukan apa saja yang diinginkan atau menguntungkan saja. Karena 
sesungguhnya mereka dalam melakukan aktivitas ekonomi tidak lepas dari ikatannya dengan iman dan akhlak yang menjadi bagian dari kewajiban agamanya.

Sebagian cendekiawan Barat telah memberikan komentar terhadap keunikan ekonomi Islam, karena terintegrasinya akhlak ke dalam aktivitas ekonomi, sementara dalam ekonomi kapitalis dan sosialis komunis, keduanya masih ada jarak. Penulis Perancis, Jack Aster dalam bukunya, Islam dan Perkembangan Ekonomi, menyatakan :

"Islam adalah sebuah sistem hidup yang aplikatif dan secara bersamaan mengandung nilai-nilai akhlak yang tinggi. Kedua hal ini berkaitan erat, tidak pernah terpisah satu dengan yang lainnya. Dari sini bisa dipastikan bahwa kaum Muslimin tidak akan menerima sistem ekonomi kapitalis. Ekonomi yang mengambil kekuatannya dari wahyu al-Qur'an pasti ekonomi yang berakhlak. Akhlak ini mampu memberikan makna baru terhadap nilai, dan mampu mengisi kekosongan pikiran yang nyaris muncul akibat alat indusrialisasi." ${ }^{\prime 31}$

Apabila kita memperhatikan kenyataan keseharian secara objektif, kita akan menemukan dampak integrasi antara ekonomi dengan akhlak terhadap kehidupan masyarakat, yaitu keamanan, ketenangan, ketentraman, keadilan, pemerataan dan sebagainya. Hal ini bisa terjadi karena menurut al-Qur'an tujuan dari aktivitas manusia - termasuk aktivitas ekonomi - hendaknya dimotivasikan untuk ibtighai mardhatillah (menuntut keridhaan Allah). Dengan demikian investasi terbaik dalam ekonomi adalah jika ia ditujukan semata-mata untuk mencari ridha Allah. ${ }^{32}$

Itulah kiat relasi akhlak dan ekonomi dalam Islam yang ditujukan untuk memperoleh ridha Allah, yakni Dzat yang mampu menciptakan kemaslahatan kita bersama.

\section{Kesimpulan}

Bertolak dari uraian di atas, dapatlah disimpulkan bahwa istilah moral, akhlak dan etika secara substansil mempunyai makna yang sama, kendati berasal dari sumber yang berbeda. Ketiganya mengandung esensi dan mengajarkan nilai-nilai luhur universal yakni kebajikan bagi sesama dan lingkungan semesta.

Ulul Albab, Vol. 5 No. 2, 2004 
Pengertian akhlak menurut terminologi Islam, jauh lebih luas daripada terminologi moral altruis menurut filsafat sosial. Ada hubungan tak terpisahkan antara akhlak dan aktivitas ekonomi. Ini berarti bahwa segala aktivitas pelaku ekonomi dibatasi dan dikendalikan oleh norma-norma akhlaki yang bersumber dari ajaran al-Qur'an dan Hadits. Konsekuensinya adalah pertanggungjawaban seluruh aktivitas itu tidak hanya kepada sesama manusia, bahkan juga kepada Tuhan.

Dampak hubungan keduanya secara realitas akan tercipta rasa keadilan, keamanan, ketentraman, kebersamaan, pemerataan dan lain sebagainya yang kesemuanya bisa dirasakan oleh masyarakat luas.

Wallahu a'lam bi al-shawab

\section{Endnotes}

1 Ayat 4 dalam surat a--Qalam tersebut dinilai sebagai konsiderans pengangkatan Nabi Muhammad Saw. sebagai Rasul. Lihat M. Quraish Shihab, Wawasan Al-Qur'an, Jakarta : Penerbit Mizan, 1996, h.253

2 Untuk jelasnya, silakan baca berbagai kitab yang membicarakan tentang akhlak. Seperti kitab-kitab al-Ghazali yang membicarakan tentang sepuluh akhlak yang terpuji dan tercela. Demikian juga kitab Ahmad Amin tentang Akhlak dan lain-lainnya.

3 AI. Purwa Hadiwardoyo, Moral dan Masalahnya, Yogyakarta : Penerbit Kanisius, 1990, h. 10

4 lbid.

5 Berkaitan dengan Moral Altruis ini, penulis sengaja menyarikan dari buku Filsafat Sosial oleh Scott Gordon yang berjudul The History and Philosophy of Social Science, London : Routledge, 1991, h. 10-13. Dalam buku ini pada bagian awal, Gordon mengkaji tentang Sociality and social science dengan sub kajiannya antara lain tentang Types of sociality. Dalam sub ini Gordon membicarakan lima tipe sosialitas, yakni gregariousness, hierarchy, biological differentiation, functional specialization, dan altruism. Dengan demikian istilah Moral Altruis sebenarnya istilah dari penulis sendiri, namun secara substansial tidak ada perbedaan dengan istilah Altruism yang dimaksudkan oleh Gordon. Substansi altruism inilah yang akan dituangkan penulis dalam diskursus ini yang diharapkan bisa menggambarkan pengertian moral altruis versus filasaf sosial.

- John M Echols dan Hassan Shadily, Kamus Inggris -Indonesia, Jakarta : PT Gramedia, 1990 , h. 25 
7 Scott Gordon, The History and Philosophy of Social Science, London : Routledge, 1991, h. 11

8 Ibid

$9 \quad$ Ibid

10 Ibid. 12

1 W.J.S. Poerwadarminta, Kamus Umum Bahasa Indonesia, Jakarta : Balai Pustaka, 1986, h. 25

12 M. Quraish Shihab, Loc. cit

13 Ahmad Amin, Etika (Ilmu Akhlak) (Penerjemah Prof. K.H. Farid Ma'ruf), Jakarta : PT Bulan Bintang, 1995, h. 2. Jadul asli buku yang menggunakan bahasa pengantar bahasa Arab adalah $A l-A k h l a q$.

Al-Qur'an dan Terjemahnya, Madinah Munawwarah : Mujamma' Al-Malik Fahd li Thiba'at Al-Mushaf Asy-Syarif, 1998, h. 1061 (QS. Al-Balad (90) : 10)

is Ibid., h. 1064 (QS. Asy-Syams (91):7-8)

16 Ibid., h. 490, (QS, Thaha (20): 121)

17 M. Quraish Shihab, Op.cit., h. 255

18 Ibid., h. 255-256

19 Al-Qur'an dan Terjemahnya, Op.cit, h. 645 (QS Ar-Rum (30):30)

20 Ibid., h. 426

21 M. Quraish Shihab, Op.cit., h. 257-258

22 Ibid., h. 259

23 Ahmad Amin, Op.cit., h. 87-90. Penulis sendiri menangkap ukuran akhlak menurut Amin ini adalah menurut ukuran yang universal, selain ukuran yang bersumber dari masing-masing ajaran agama, termasuk ajaran Islam

\section{Klasik untuk Memahami dan /atau Menjelaskan Hakikat Ketertiban Dalam Kehidupan Bermasyarakat Manusia (Bahan Kuliah Program Doktor IAIN Sunan} Ampel Surabaya, 2003). Suraboya, 2003

26 Scott Gordon, Op.cit., h. 135

27 lbid.

28 Ibid.

29 Yusuf Qardhawi, Peran Nilai dan Moral dalam Perekonomian Islam (Penerjemah : K.H. Didin Hafidhuddin, M.Sc, dkk), Jakarta ; Robbani Press, 1997, h.23

30

Ulul Albab, Vol. 5 No. 2, 2004 
31 Dikutip dari Yusuf Qardhawi, Ibid., h. 61

32 Mustaq Ahmad, Etika Bisnis dalam Islam (Penerjemah : Samson Rahman), Jakarta : Pustaka Al-Kautsar, 2001, h. 38

\section{Bibliography}

Ahmad, Mustaq, Etika Bisnis dalam Islam (Penerjemah : Samson Rahman), Jakarta : Pustaka Al-Kautsar, 2001

Al-Qur'an dan Terjemahnya, Madinah Munawwarah : Mujamma' Al-Malik Fahd li Thiba' at Al-Mushaf Asy-Syarif, 1998

Amin, Ahmad, Etika (Ilmu Akhlak) (Penerjemah : Prof.K.H. Farid Ma'ruf), Jakarta : PT Bulan Bintang, 1995

Echols, John M, Hassan Shadily, Kamus Inggris-Indonesia, Jakarta ; PT Gramedia, 1990

Gordon, Scott, The History and Philosophy of Social Science, London ; Routledge, 1991

Hadiwardoyo, AI Purwa, Moral dan Masalahnya, Yogyakarta : Penerbit Kanisius, 1990

Poerwadarminta, W.J.S., Kamua Umum Bahasa Indonesia, Jakarta ; Balai Pustaka, 1986

Qardhawi, Yusuf, Peran Nilai dan Moral dalam Perekonomian Islam (Penerjemah :K.H. Didin Hafidhuddin dkk), Jakarta : Robbani Press, 1997

Shihab, M. Quraish, Wowasan Al-Qur'an, Jakarta : Penerbit Mizan, 1996

Wignjosoebroto, Soetandyo, Handout 'Filsafat Sosial' tentang Dua Paradigma Klasik untuk Memahami dan/atau Menjelaskan Hakikat Ketertiban Dalam Kehidupan Bermasyarakat Manusia (Bahan Kuliah Program Doktor IAIN Sunan Ampel Surabaya, 2003), Surabaya, 2003 